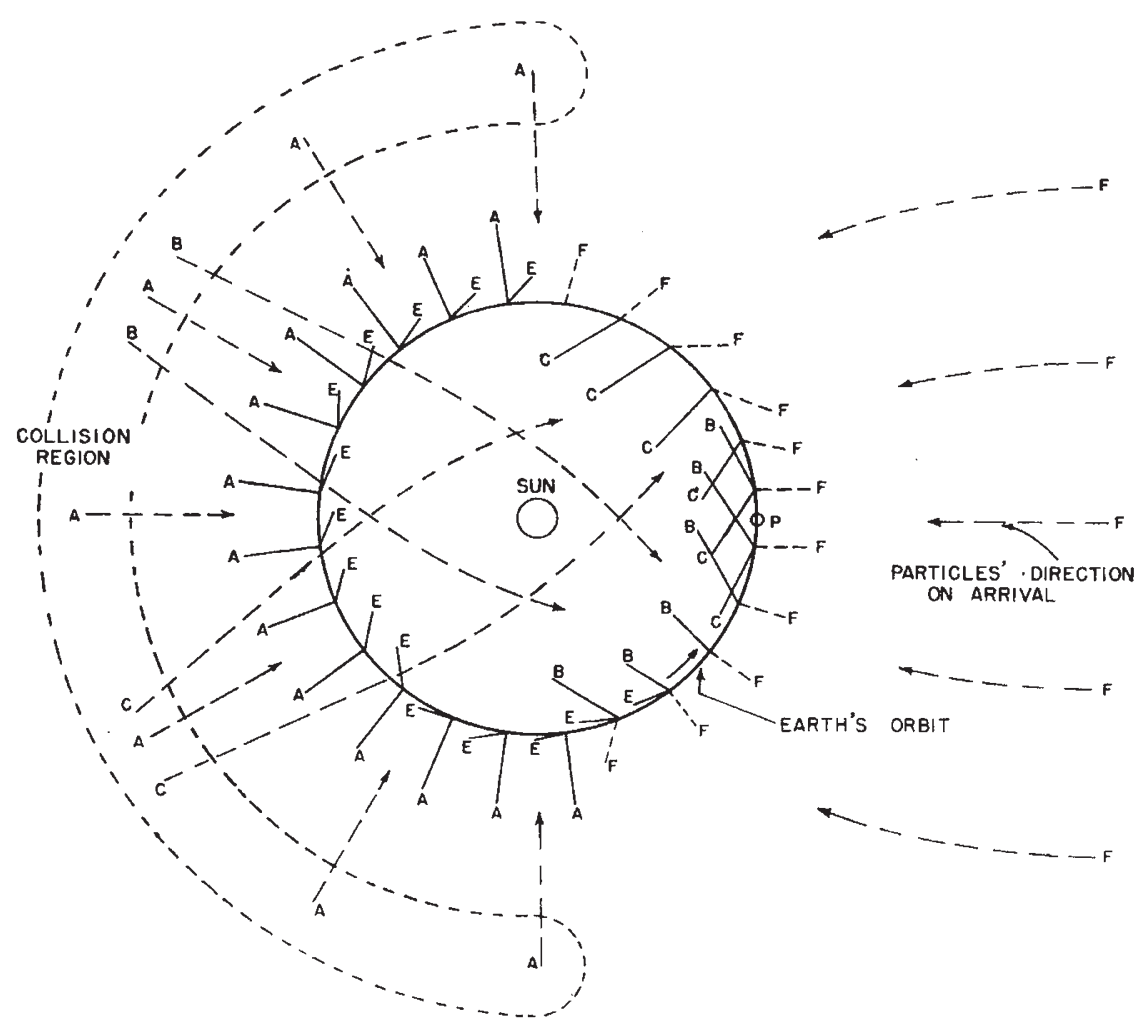

Fig. 2. Connexion between the accretion of interstellar matter by the Sun and the observed scintillations of radio stars. The Earth traverses its circular orbit about the Sun and is at the point $P$ on
June 8 approximately. Interstellar particles, arriving from the right, form a collision region behind the Sun-shown here schematically as a dotted hemispherical region. Particles arriving both directly and from the collision region are believed responsible for the scintillation observations. The apparent positions of the Earth on its orbit, as derived from the scintillation measurements presented in Fig. 1

$400-\mathrm{km}$. level believed to be important here; and further, show no correla. tion between meteor act ivity and radio star scintillations. Secondly, the Sun's radiation pressure would remove small dust particles from its vicinity while allowing hydrogen atoms to fall inward.

Combining information about solar times of maximum occurrence of scintil lations with the observed annual variation (the Earth is determined to be on the forward side of the Sun on June 8) allows the celestial radiant of the infalling hydrogen to be estimated. The radiant appears to lie within the limits : right ascension $16 \mathrm{~h} .40 \mathrm{~m}$. to $17 \mathrm{~h}$. and declination $-20^{\circ}$ to $-40^{\circ}$. In addition, the components of the velocity of the particles with respect to the galactic plane can be estimated as follows : tangential, $28 \times$ $10^{4} \mathrm{~m} . / \mathrm{s}$. (the particles are judged to be overtaking the Sun from behind), radially outward $2 \times 10^{4} \mathrm{~m} . / \mathrm{s}$., and trans. verse $0.2 \times 10^{4} \mathrm{~m} . / \mathrm{s}$.

A detailed account of these measurements and

higher, which may be related to the fact that the only solar flares of 1954 occurred during that period. There was no other evidence in the scintillation measurements of effects directly attributable to the Sun.

The kind of particles involved must depend on the kind of interstellar matter available. On that basis, only hydrogen atoms and interstellar dust need be considered. Two arguments strongly favour hydrogen. First, meteor studies suggest that dust particles produce ionization only at altitudes lower than the the analysis performed will be published elsewhere.

The scintillation measurements used here were made by T. R. Hartz, who also, with P. A. Forsyth and C. O. Hines, gave much helpful advice. The work was carried out at the Radio Physics Laboratory of the Defence Research Board, Ottawa.

${ }^{1}$ Hewish, A., Proc. Roy. Soc., A, 214, 494 (1952).

${ }^{2}$ Ryle, M., and Hewish, A., Mon. Not. Roy. Astro. Soc., 110, 381 (1950). 'Ginzburg, V. L., Dok. Acad. Nauk, U.R.S.S., 84, 245 (1952).

- Hoyle, F., and Lyttleton, R. A., Proc. Camb. Phil. Soc. 35, 405 and

\title{
OBITUARY
}

\section{Prof. R. N. Rudmose Brown}

Dr. Robert Neal Rudmose Brown, emeritus professor of geography in the University of Sheffield, died on January 27 in his seventy-eighth year. Born on September 13, 1879, he was educated at Dulwich College, the University of Aberdeen and the University of Montpellier. By training, a botanist with a strong inclination for field-study, he held the post of assistant professor of botany in University College, Dundee, during 1900-2. But he yearned for exploration and in 1902 was appointed naturalist to the Scottish National Antarctic Expedition, which for two years sounded and charted 10,000 miles of unexplored Antarctic seas. For his part in this work he was awarded the Medal of the Royal Scottish Geographical Society.

In 1904 he was appointed assistant at the Scottish Oceanographical Laboratory, and in 1906 visited Burma to report to the Government of India on the pearl oyster fisheries of the Mergui Archipelago. Later, in 1909, 1914 and 1919, he served as surveyor and naturalist on three Scottish Arctic expeditions to Spitsbergen, on which region he became an acknowledged authority and for which work he was awarded the Cuthbert Peak Grant of the Royal Geographical Society. His interest in polar regions never waned. In 1907 he was elected vice-president of the International Polar Congress; in 1932 president of the Antarctic Club, and in 1949 of the Arctic Club. 
In the earlier years of his career Rudmose Brown was much influenced by the thought and teaching of Patrick Geddes, and by some of the earliest pioneer teachers of geography-a now subject that was then only just emerging, at the beginning of the century, to replace the teaching of 'capes and bays'. When, in 1908, the University of Sheffield took, for that time, the very progressive step of creating a Department of Geography, Rudmose Brown was appointed its first head. The development of the new subject and the new Department became his life's work, and he will always be remembered as one of the leading pioneer teachers in that field, who did much to promote the status of geography as an academic discipline in Britain, through the critical early decades of its development. From the start he placed great emphasis on the importance of the physical basis as the foundation and core of the subject, to which human and regional studies must be welded later, and his approach gave the work of his Department at Sheffield a distinctive character.

His own numerous published researches were mainly concerned with polar geography, on which he wrote many texts of acknowledged standing. But his scholarship and interests covered very many fields, and included a standard text-book of economic geography, and a contribution to a text-book on the scope and teaching of the subject. As a lecturer he was renowned for his lucidity and powers of exposition, no less than for the diverse fields of the subject over which his interests ranged. For a number of years he contributed much appreciated notes and articles on geographical topics to the columns of Nature.

In 1931 a chair of geography was created at Sheffield, and Rudmose Brown was appointed professor, a post which he held until his retirement in 1945 after thirty-seven years of service. For two years, 1920-22, he also held the post of reader in geography in the University of Manchester, jointly with his post in Sheffield. During the First World War he was seconded to the Admiralty Intelligence Division and some of this work he continued during the Second World War, for which confidential services King Haakon of Norway awarded him the insignia of the Commander of the Order of St. Olav.

Rudmose Brown's scholarship brought recognition in many academic spheres. He was president of Section E (Geography) in 1927 and a member of Council from 1933 until 1938 of the British Association for the Advancement of Science; he served on the Council of the Royal Geographical Society during 1925-28, and again during 1945-46. In 1938-39 he was elected president of the Institute of British Geographers-the second holder of this important office.

A. GarnetT

\section{NEWS and VIEWS}

Ministry of Supply: Aircraft Mechanical Engineering: $\quad$ Mr. Robert Graham, C.B.E.

Mr. Robert Graham retired from the post of director of Aircraft Mechanical Engineering Research and Development, with the Ministry of Supply, in January 1957, after thirty-nine years of government service. He was born in Glasgow in 1894 and after attending the Gateshead Secondary School and Darlington Technical College, served an engineering apprenticeship with Messrs. Robert Stephenson, locomotive builders, at Darlington: his apprenticeship was broken by two years overseas service in H.M. Forces. Mr. Graham joined the government service under the Air Board in 1917. In 1920 he was seconded to act as chief engineer to Mr. Louis Brennan, who was designing and developing the Brennan helicopter under Air Ministry sponsorship. The aircraft was completed in 1925 and Mr. Graham acted as test pilot throughout its trials. Although the aircraft showed considerable promise and a number of short free flights were made, it was decided to abandon the project, following damage in a minor accident, because the Air Ministry was advised that the autogyro held more promise of success than the helicopter. In 1926, Mr. Graham joined the Airworthiness Department of the Royal Aircraft Estab. lishment, but maintained a private collaboration with Brennan in the development of a gyroscopically stabilized two-wheeled motor-car. A successful vehicle was produced but it was found that all such vehicles suffered from an inherent disability which made them unsafe for use on the public highway, and the project was abandoned. After serving during 1928-38 as resident technical officer at some of the major aircraft firms, Mr. Graham was put in charge of the Mechanical Engineering Division of the Structures and Mechanical Engineering Department at the Royal Aircraft Establishment, where he was chiefly engaged on research into pressure cabins and other equipment for high-altitude flying and into aircrew safety. When the Department was split up in 1946, he became the first head of the Mechanical Engineering Department and in 1950 was appointed director of aircraft research and development at the Ministry of Supply headquarters in London. In a subsequent re-organization of the London headquarters, Mr. Graham was appointed to the post from which he has recently retired. Since his retirement Mr. Graham is maintaining his interest in aeronautical engineering and has taken up an appointment as technical director of Messrs. Microcell, Ltd.

Mr. E. A. Poulton

Mr. E. A. Poultow has been appointed to the post of director of aircraft mechanical engineering equipment research and development at the Ministry of Supply in succession to Mr. R. Graham. Born in 1915, Mr. Poulton was educated at Bournemouth School and Bournemouth Municipal College. $\mathrm{He}$ gained a Royal Scholarship to the City and Guilds College, where he graduated in mechanical engineering with first-class honours in 1937. After a year's postgraduate study in aeronautics he joined the Supermarine Works of Vickers-Armstrongs, Ltd., and later became technical officer to the Air Registration Board. With the cessation of civil aviation in the early months of the War he transferred to the Royal Aircraft Establishment and, later, to the Ministry of Aireraft Production headquarters, where his main objective was to shorten the period between new research discoveries and their application in aircraft design. In February 1946 he returned to the Royal Aircraft Establishment and became superintendent of the Structural Research Division. His 